\title{
Protease inhibitors of Manduca sexta expressed in transgenic cotton
}

\author{
John C. Thomas ${ }^{1, *}$, Deanna G. Adams ${ }^{1}$, Veronique D. Keppenne ${ }^{2}$, Catherine C. Wasmann ${ }^{3}$, \\ Judith K. Brown ${ }^{2}$, Michael R. Kanost ${ }^{4}$, and Hans J. Bohnert ${ }^{1,2}$ \\ 1 Department of Biochemistry, University of Arizona, Tucson, AZ 85721, USA \\ 2 Department of Plant Sciences, University of Arizona, Tucson, AZ 85721, USA \\ 3 Department of Plant Pathology, University of Arizona, Tucson, AZ 85721, USA \\ 4 Department of Biochemistry, Kansas State University, Manhattan KS 66506-0001, USA \\ * Present address: Department of Natural Sciences, University of Michigan-Dearborn, Dearborn MI 48128-1491, USA
}

Received 22 June 1994/Revised version received 6 March 1995 - Communicated by J. J. Finer

Summary. To explore the effectiveness of insect derived protease inhibitors in protecting plants against insect feeding, anti-trypsin, anti-chymotrypsin and anti-elastase protease inhibitor (PI) genes from Manduca sexta $\mathrm{L}$. were expressed in transgenic cotton (Gossypium hirsutum L.). From 198 independent transformants, 35 elite lines were further analyzed. Under the control of the $35 \mathrm{~S}$ promoter of CaMV, PI accumulated to approximately $0.1 \%$ of total protein, depending on the tissue analyzed. Using cell-flow cytometry, DNA content/ nuclei of transgenic and nontransformed cotton were identical. On cotton plants expressing PIs, fecundity of Bemisia tabaci (Genn.), the sweetpotato whitefly, was reduced compared to controls. Expression of these protease inhibitors may reduce the developmental rate of $B$. tabaci and other insects, and provide a strategy for cotton protection.

Key Words: Protease inhibitor - Plant transformation

\section{Introduction}

Insects such as pink boll worm, cotton boll worm, and cotton boll weevil can cause up to a 50\% cotton crop loss (Schwartz 1983) even when using chemical pesticides, pheromones, insect parasites, and modified cropping practices. Feeding damage, fiber contamination with honeydew and whitefly transmitted viral diseases have significantly contributed to the loss of cotton (Brown and Bird 1992), requiring new methods of control without increasing the use of pesticides. One approach to insect control is to express the anti-insect compound within transgenic cotton. Using this strategy, expression of Bacillus thuringiensis $(\mathrm{Bt})$ toxins have protected cotton against certain lepidoptera (Perlack et al. 1990).

In most plants, natural mechanisms to control insect attack include protease inhibitor (PI) accumulation (Ryan 1973). Addition of PIs to insect diets have been shown to limit insect development (Gatehouse et al.

Correspondence to: J. C. Thomas
1980; Broadway and Duffy 1986a). Thus, the overexpression of PI's in transgenic plants may decrease insect damage (Hilder et al. 1987; Johnson et al. 1989).

Protease inhibitor genes isolated from $M$. sexta have been expressed in transgenic alfalfa and tobacco to test their use in insect control (Thomas et al. 1995; unpublished). A cDNA encoding an anti-elastase protease inhibitor was described previously (Kanost et al. 1989). PCR-based in vitro mutagenesis was used to alter the active site to generate chymotrypsin-specific or trypsin-specific inhibitors. The three genes were placed under the control of two promoters, the $35 \mathrm{~S}$ promoter of CaMV or the phosphoenolpyruvate carboxylase $(P p c-1)$ of Mesembryanthemum crystallinum, and then transferred into cotton. Here we report the expression of these protease inhibitors and decreased pupae emergence of Bemisia tabaci (strain B) on the transgenic plants compared to controls.

\section{Materials and methods}

Cloning and manipulations. A full length cDNA encoding the antielastase protease inhibitor was $\mathrm{N}$-terminally extended to include a second initiation ATG and 5 subsequent amino acids from the transit peptide of the RUBISCO small subunit resulting in a protein of an approximate $\mathrm{M}_{\mathbf{r}}$ of $47 \mathrm{kD}$ (Kanost et al. 1989; Thomas et al. 1995). Anti-chymotrypsin and anti-trypsin enzyme activity was predicted when the ALA at position amino acid number 343 was changed to PHE or LYS respectively (see Kanost et al. 1989). The P1 site from anti-elastase (GGTATCGTACCGGCG AGTTTGATACTA) was converted to anti-chymotrypsin (GGTATCGTACCGITTAGTTTGATACTA) and anti-trypsin (GGTATCGTACCGAAGAGTTTGATACTA) using PCR-based oligonucleotide-directed mutagenesis according to Hemsley (et al. 1989). Promoters used were the 35S (Benfey et al. 1990) or double enhancer 35S promoter from CaMV (Guerineau et al. 1988) and the phosphoenol pyruvate carboxylase promoter from $M$. crystallinum (Cushman et al. 1989) with the $3^{\prime} 19 \mathrm{~S}$ polyA site from CaMV. Using standard molecular methods, DNA constructions were placed into a plant transformation vector (Bevan 1984), subsequently mated into Agrobacterium tumefaciens LBA4404 and verified using Southern hybridization.

Plant transformation/regeneration. A. tumefaciens-mediated gene transfer into Gossypium hirsutum L. var. Coker 312 used adaptations 
of existing methods (Umbeck et al. 1987; Firoozabady et al. 1987; Bayley et al. 1992). Seeds were surface sterilized in $70 \%(\mathrm{v} / \mathrm{v})$ ethanol for $30 \mathrm{~s}$, soaked for $15 \mathrm{~min}$ in $10 \%(\mathrm{v} / \mathrm{v})$ Clorox solution containing 1 drop of Tween 20 per $250 \mathrm{ml}$, washed three times, soaked in sterile water 30-60 min and germinated on G1 medium (hormone-free MS medium containing $3 \%(\mathrm{w} / \mathrm{v})$ glucose) at $25^{\circ} \mathrm{C}$, $16 \mathrm{~h}$ light, $30-50 \mu$ moles PPFD m $\mathrm{m}^{-2}$. Cotyledons from 3-14 day old plants were sliced into $5 \times 2 \mathrm{~mm}$ segments and co-cultivated in approximately $10^{8} / \mathrm{ml}$ A. tumefaciens on G1 medium. After 3 days, explants were placed on G2 medium (MS medium with $100 \mathrm{mg} / \mathrm{L}$ inositol, $1 \mu \mathrm{M}$ thiamine $\mathrm{HCl}, 25 \mu \mathrm{M}$ 6- $(\gamma$ - $\gamma$-dimethylallylamino)purine (2iP), $0.5 \mu \mathrm{M}$ naphthaleneacetic acid (NAA), $3 \% \mathrm{w} / \mathrm{v}$ glucose, $\mathrm{pH} 5.8$ in $0.2 \%$ Gelrite (Kelko) with $15-50 \mathrm{mg} / \mathrm{L}$ kanamycin and $400 \mathrm{mg} / \mathrm{L}$ carbenicillin at $30^{\circ} \mathrm{C}, 16 \mathrm{~h} \mathrm{light}$ and $100 \mu$ moles PPFD $\mathrm{m}^{-2} \mathrm{~s}^{-1}$. Two to four week old calli were subcultured to identical media, then subcultured one month later to MSOB medium (MS salts, Gamborg's B-5 vitamins, additional $500 \mathrm{mM} \mathrm{KNO}_{3}$, $2 \mathrm{mM} \mathrm{MgSO}_{4}$ and $0.16 \%$ Gelrite supplemented with $200 \mathrm{mg} / \mathrm{L}$ carbenicillin and $50 \mathrm{mg} / \mathrm{L}$ kanamycin). Arising embryos were individually placed on MSBO medium, the shoots propagated on MSBO medium without antibiotics, rooted on MS3 medium (MS salts, $0.4 \mu \mathrm{M}$ thiamine $\mathrm{HCL}, 0.5 \mu \mathrm{M}$ pyridoxine $\mathrm{HCL}$ and $0.8 \mu \mathrm{M}$ nicotinic acid, $1 \%$ glucose, $0.8 \mathrm{~g} / \mathrm{L}$ Gelrite and $4 \mathrm{~g} / \mathrm{h}$ Difco Bacto agar), trausferred to pots, grown and selfed in a greenhouse. Segregation of the T-1 generation was screened using cotyledonderived callus formation on $\mathrm{G} 2$ medium containing $50 \mu \mathrm{g} / \mathrm{ml}$ kanamycin as a criteria for transformation.

DNA pg/nuclei. Analysis of the nuclear DNA with cell-flow cytometry was done according to Galbraith et al. (1983).

Western analysis. Transformed and non-transformed leaves, cotyledons and other tissues were extracted in $100 \mathrm{mM}$ Tris $\mathrm{HCl}, \mathrm{pH}$ $8,100 \mathrm{mM} \mathrm{NaCl}, 20 \mathrm{mM}$ EDTA, $10 \mathrm{mM}$ DTT. Total protein was quanitated (Ghosh et al 1988), separated on 12.5\% SDS-PAGE, blotted to nitrocellulose $(0.45 \mu \mathrm{m})$, reacted with rabbit antiserum made to purified anti-elastase of $M$. sexta, and the PI band located with a secondary goat-anti-rabbit antibody conjugated to peroxidase (Sigma). Estimates of PI accumulation were based on western blot comparisons of transgenic plant extracts to several dilutions of semipurified PI from $M$. sexta hemolymph (Kanost et al 1989; Thomas et al 1995).

Whitefly protease assay. To examine whether B. tabaci contained detectable protease activity, three individual lots of 125 adults were extracted in $10 \mathrm{mM}$ Tris $\mathrm{pH} 7.5$ and $50 \mathrm{mM} \mathrm{NaCl}$ and reacted at $25^{\circ} \mathrm{C}$ with $\mathrm{N}$ - $\alpha$-benzoyl-DL-arginine p-nitroaniline (Sigma). Crude whitefly extracts contained $1.61+/-0.54$ units of trypsin activity $\mathrm{mg}^{-}$ ${ }^{1} \mathrm{~h}^{-1}$ total protein in comparison to $2.40+/-0.32$ units $\mathrm{mg}^{-1} \mathrm{~h}^{-1}$ total protein found in Drosophilia melanogaster adults. Dissection and subsequent characterization of the small whitefly digestive system was not attempted.

Whitefly toxicity/aversion bioassay. To test insecticidal activity of the PIs from $M$. sexta, whitefly bioassays were performed on plants expressing or not expressing different PI proteins. Cotton plants were approximately 4 weeks olds when testing began. Growth conditions were similar to those described above, $28^{\circ} \mathrm{C}, 16 \mathrm{~h}$ light and $100 \mu$ moles PPFD m ${ }^{-2} s^{-1}$. Fourty adults ( 20 of each sex) were surrounded by a plexiglass cylinder with $250 \mu \mathrm{m}$ netting on T-1 selfed cotton plants (each plant was tested in triplicate). Adult insects were allowed to mate, deposit eggs, and were removed after 3 days. Following an incubation period of 25-30 days, pupae cases were counted.

\section{Results and Discussion.}

\section{Transgenic plants}

Cotton transformation/regeneration procedures were largely as described (Firoozabady et al. 1987).
Selection for transformed cotton calli on $50 \mu \mathrm{g} / \mathrm{ml}$ kanamycin produced low rates of non-transformed (escape) plants compared to $15-25 \mu \mathrm{g} / \mathrm{ml}$ kanamycin, where $95 \%$ of the plants recovered were not transformed. Transformed tissues grew at a rate comparable to non-transformed cells on G2 medium without antibiotics. Once embryogenic calli emerged, $500 \mathrm{~mm}^{2}$ pieces were subcultured repeatedly until somatic embryos were obtained. Embryos were subcultured to MSBO medium with $50 \mu \mathrm{g} / \mathrm{ml}$ kanamycin and shoots developed, which were subsequently rooted and hardened off in soil. Thirty five elite lines were further analyzed from 198 independent transformants, their selection based on PI expression and the ability to develop vigorous roots, thrive in soil and reproduce (self) easily. T-1 segregation indicated $80 \%$ (28) of the selected transgenic cotton segregated as a single PI-kanamycin resistance locus, while others (7) contained greated than 1 loci. Transformed and regenerated cotton plants had DNA contents indistinguishable from those found in non-transformed cotton; $4.39+/-0.17 \mathrm{pg} /$ nuclei $(\mathrm{N}=15)$ versus $4.30+/-0.07 \mathrm{pg} /$ nuclei $(\mathrm{N}=3)$ respectively.

\section{Protease inhibitor expression}

A large variation in the expression of transgenic genes has been observed when gene expression was under the control of the $35 \mathrm{~S}$ promoter (Williamson et al 1989). Most (74\%) of the plants containing the $35 \mathrm{~S}$ promoter with the PI constructions were kanamycin resistant and also accumulated $\mathrm{Pl}$, as detected on western blot analysis. Generally, anti-trypsin and antichymotrypsin PI accumulated to higher amounts than anti-elastase protein as shown by immunological detection (Figure 1A, 1B). Apart from a protein migrating at the expected size of the fusion protein, approximately $48 \mathrm{kDa}$, a slightly faster migrating band was observed, perhaps the result of proteolysis or initiation at the ATG codon of the native $M$. sexta PI gene (see Material and Methods). In addition, bands corresponding to kigher apparent molecular mass were observed in plants that expressed large amounts of PI which may represent PI aggregates (Figure 1B, antitrypsin lane 4).

Gene expression also varied depending on the tissue source. An often observed, or "typical" tissue-specific expression pattern for the PI proteins expressed under control of the 35S promoter is shown in Figure 2. Mature leaves and bracts contained the greatest amount of PI, with concentrations up to $0.1 \%$ of total protein (Figure 2).

We tested two plant promoters, $35 \mathrm{~S}$ of CaMV (both the single and double enhancer version) and $P p c-1$ from $M$. crystallinum for expression of the PIs. Both $35 S$ promoter types led to similar levels of PI accumulation as determined by antibody detecting PI protein on a western blot (see Figure 3). Ppc-I in $M$. crystallinum was induced by environmental stress (Cushman et al. 1989) and in this species was able to 

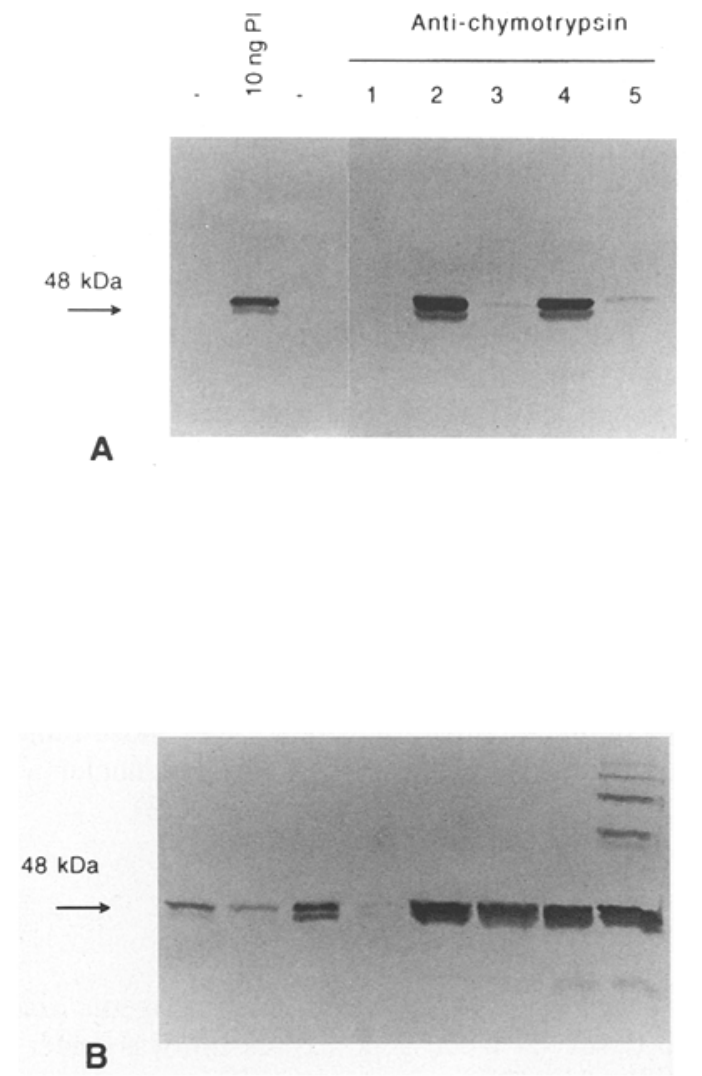

Fig. 1. Immunological detection of anti-elastase, anti-chymotrypsin and anti-trypsin in cotton plants. A. Ten nanograms of semi-purified anti-elastase from $M$. sexta serum were separated with SDS-PAGE, blotted to nitrocellulose and reacted with the rabbit anti-PI antibody (10 ng PI). Thirty micrograms of total leaf protein from different 35S-anti-chymotrypsin plants (lanes 1-5) were separated, reacted with anti-PI antibody and compared to the intensity of the antibody reaction for $10 \mathrm{ng}$ PI. Detection was with goat anti-rabbit $2^{\circ}$ antibody coupled to peroxidase. Arrow indicates a protein of molecular mass $48 \mathrm{kDa}$. B. Lanes 1-4 are from different 35S-antielastase plants and lanes 5-8 are 35S-anti-trypsin plants (1-4). Antibody and gel conditions were as in A.

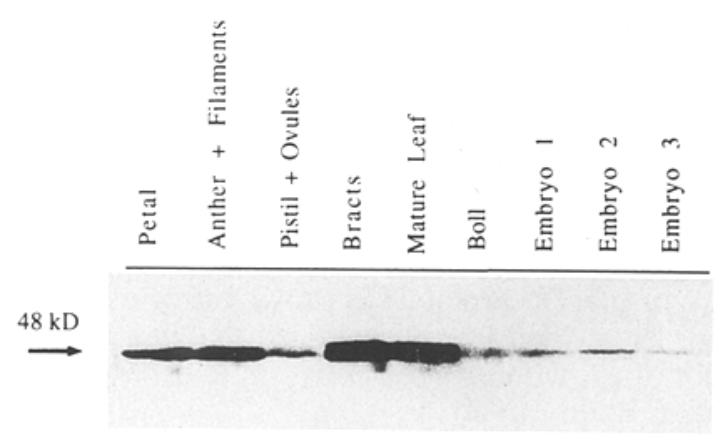

Fig. 2. Tissue specific accumulation of anti-elastase under the control of the $35 \mathrm{~S}$ promoter of CaMV. $25 \mu \mathrm{g}$ of total protein from each tissue source was separated on SDS-PAGE, blotted and reacted with anti-PI antibody as in Figure 1. This "typical" transgenic plant was a 35S-anti-elastase plant. Similar patterns of expression were observed in 4 other plants.

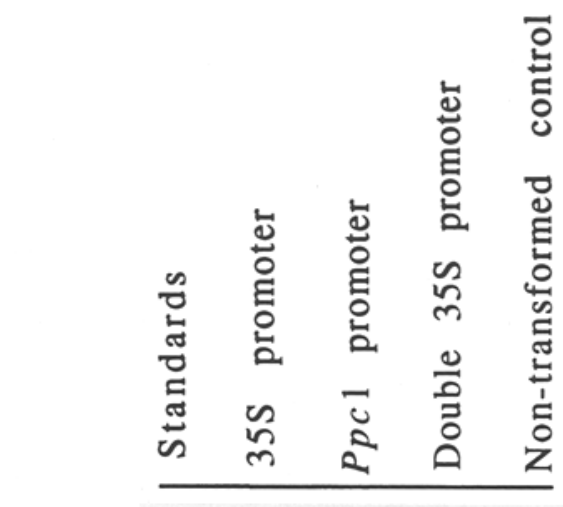

Fig. 3. Effect of promoter on PI accumulation in transgenic cotton. Leaf total protein $(20 \mu \mathrm{g})$ of several transgenic plants was separated and reacted to the anti-PI antibody as in Figure 1 and 2.

stimulate expression of a reporter gene (Schaeffer and Cushman 1994). However, when used in transgenic cotton; the Ppc-1 promoter did not lead to PI accumulation either when plants were kept at optimal conditions, or under stress conditions (Figure 3; data not shown). This finding was similar to results obtained in Medicago sativa L. (alfalfa) and Nicotiana tabacum (tobacco) (Thomas et al. 1995; unpublished). No further studies were conducted with these $P p c-1$ gene constructions. It is known that promoters which function well in one species may be less effective in another in inducing transcription of foreign proteins (Narvaéz-Vásquez et al. 1992).

\section{Whitefly bioassay activity}

From two separate experiments non-transformed cotton contained $224+/-30$ pupae cases, while an antitrypsin (\#114) and an expressing anti-elastase transformant (\#37) had reduced numbers of emerged whiteflies (Figure 4). An anti-elastase non-expressing transformant (\#125) allowed emergence of pupae similar to controls while an anti-chymotrypsin plant \#34 inhibited whitefly development compared to controls (Figure 4). Four T-1 plants from each transgenic line were tested in each experiment.

Protease inhibitors arrest digestive enzymes in the insect gut (Ryan 1973). When insects feed, plant- 


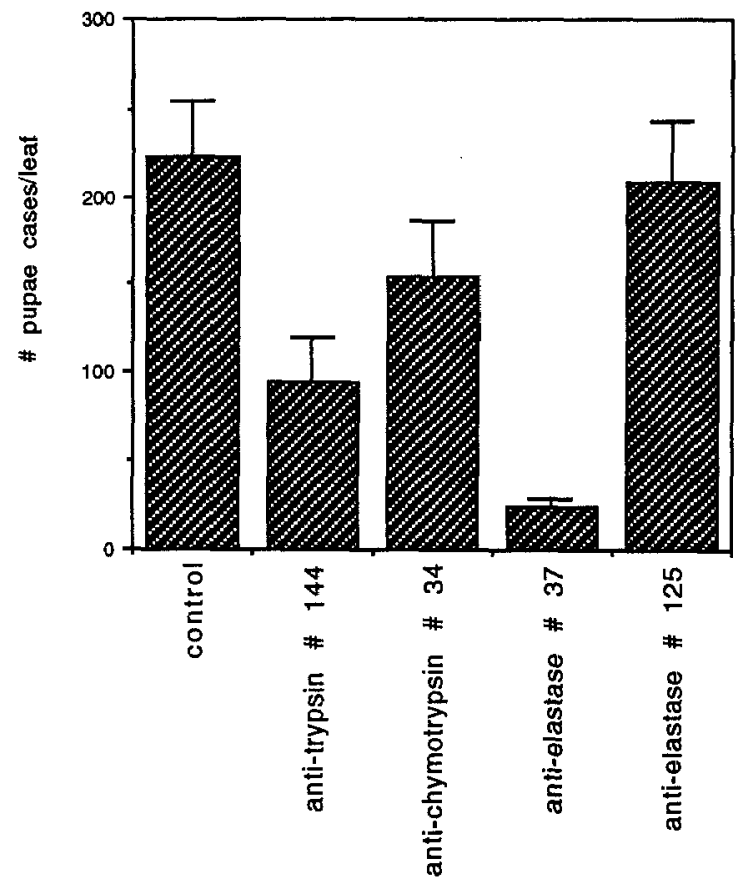

Fig. 4. Adult whitefly $B$. tabaci type B emergence from PI expressing cotton. Fourty adults ( 20 of each sex) were placed on leaves of T-1 selfed cotton plants and adults allowed to mate and deposit eggs. After 30 days, emerged pupae were counted on the plants. Plant number indicates an individual and unique transformation event. Controls were non-transformed plants.

encoded PI's are accumulated in non-damaged areas of the plant near the feeding site (Green and Ryan 1972), resulting in a decrease in value as a food source (Broadway et al. 1986a; 1986b). Over-expression of introduced PIs has been shown to protect plants against damage caused by some insects (Hilder et al. 1987; Johnson et al. 1989). Some PI's are more effective when presented to insects in a low protein diet, while other inhibitors act to retard insect growth in either high or low protein-containing artificial diets (Burgess et al. 1991). Diets containing trypsin inhibitors reduced growth rate of Heliothis zea, but measurable trypsin activity in the insect gut increased (Broadway and Duffy 1986b; Burgess et al. 1991). PI mediated hyperproduction of digestive enzymes could result in decreased concentrations of sulfur containing amino acids, thus indirectly inhibiting insect growth (Ryan 1990).

Expression of Manduca sexta PIs in transgenic alfalfa, tobacco and cotton (Thomas et al. 1995; unpublished) was associated with decreased whitefly adult emergence when compared to control plants. PI expression varied from tissue to tissue, suggesting that tissue specific expression of PI's will be a goal to increase effectiveness against insect feeding. Such an approach would be particularly effective if bollspecific and/or epidermis specific promoters were employed. In addition, protease inhibitors could be expressed in transgenic plants together with other antiinsect substances with different modes of action within the same transgenic crop, such as $B$. thuringensis toxin (MacIntosh et al. 1990). This combinatorial approach would lower the incidence of insect resistance to individual insecticides.

Acknowledgments. This work was supported by the Arizona Cotton Growers Association, a stipend from the University of Arizona College of Agriculture (to JCT), and an Undergraduate Biology Reasearch Program award (NSF) to DGA. We thank D. Galbraith and G. Lampert for help with DNA analysis, C.B. Michalowski for DNA constructions, F. Herzfeld for the double $35 S$ promoter, and J.C. Cushman for the $P p c-1$ promoter.

\section{References.}

Bayley C, Trolinder NL, Ray C, Morgan M, Quisenberry JE, OW DW (1992) Engineering 2,4-D resistance into cotton. Theor Appl Genet 83: 645-649

Benfey PN, Ren L, Chua N-H (1990). Tissue-specific expression from CaMV $35 \mathrm{~S}$ enhancer subdomains in early stages of plant development. EMBO J. 9: 1677-1684

Bevan M (1984) Binary Agrobacterium vectors for plant transformation. Nucleic Acids Res 12:8711-8721

Broadway RM, Duffey SS (1986a) Plant protease inhibitors: mechanism of action and effect on the growth and digestive physiology of larvae Heliothis zea and Spodoptera exiqua. J Insect Physiol 32: 827-833

Broadway RM, Duffey SS, Pearce G, Ryan CA (1986b) Plant protease inhibitors: a defense against herbivorous insects? Ent Exp Appl 41: 33-38

Brown JK, Bird J (1992) Whitefly transmitted geminiviruses in the Americas and the Caribbean Basin: past and present. Plant Disease 76: 220-225

Burgess EPJ, Stevens PS, Keen GK, Laing WA, Christeller JT (1991) Effects of protease inhibitors and dietary protein level on the black field cricket Teleogryllus commodus. Entomol Exp Appl 621: 123-130

Cushman JC, Meyer G, Michalowski CB, Schmitt JM, Bohnert HJ (1989) Salt stress leads to differential expression of two isogenes of phosphoenolpyruvate carboxylase during Crassulacean acid metabolism induction in the common ice plant. Plant Cell 1:715725

Firoozabady E, DeBoer DL, Merlo DJ, Halk EL, Amerson LN, Rashka KE, Murray EE (1987) Transformation of cotton (Gossypium hirsutum L.) by Agrobacterium tumefaciens and regeneration of transgenic plants. Plant Mol Biol 10: 105-116

Galbraith DW, Harkins KR, Maddox JM, Ayres NM, Sharma DP, Firoozabady E (1983). Rapid flow cytometric analysis of the cell cycle in intact plant tissues. Science 220: 1049-1051

Gatehouse AMR, Gatehouse JA, Boulter D (1980) Isolation and characterization of trypsin inhibitors from cowpea Phytochemistry 19: 751-756

Ghosh S, Gepstein S, Heikkila JJ, Dumbroff EB (1988) Use of a scanning densitometer or an ELISA plate reader for measurement of nanogram amounts of protein in crude extracts from biological tissues. Analytical Biochemistry 169: 227-233

Green TR, Ryan CA (1972) Wound-induced proteinase inhibitor in 777 plant leaves: a possible defense against insects. Science 175: 776-

Guerineau F, Woolston S, Brooks L, Mullineaux P (1988) An expression cassette for targeting foreign proteins into chloroplasts. Nucleic Acids Research 16: 11380.

Hemsley A, Arnheim N, Toney MD, Cortopassi G, Galas DJ (1989) A simple method for site-directed mutagenesis using the polymerase chain reaction. Nucleic Acids Res 17: 6545-6551

Hilder VA, Gatehouse AMR, Sheerman SE, Barker RF, Boulter D (1987) A novel mechanism of insect resistance engineered into tobacco. Nature 330: 160-163

Johnson R, Narvaéz J, An G, Ryan CA (1989) Expression of proteinase inhibitors $I$ and II in transgenic tobacco plants: effects on natural defense against Manduca sexta larvae. Proc Nat Acad Sciences 86: 9871-9875

Kanost MR, Sarvamangala VP, Wells MA (1989) Primary structure of a member of the serpin superfamily of proteinase inhibitors from an insect Manduca sexta. J Biol Chem 264: 965- 
MacIntosh SC, Kishore GM, Perlak FJ, Marrone PG, Stone TB, Sims SR, Fuchs RL (1990) Potentiation of Bacillus thuringensis insecticidal activity by serine protease inhibitors. J Agric Food Chem 38: 1145-1152

Narvaéz-Vásquez J, Orozco-Cárdenas MT, Ryan CA (1992) Differential expression of a chimeric CaMV-tomato proteinase inhibitor I gene in leaves of transformed nightshade, tobacco and alfalfa plants. Plant Mol Biol 20: 1149-1157

Perlak, F.J., Deaton, R.W., Armstrong, 'T.A., Fuchs, R.L., Sims, S.R., Greenplate, J.T. and Fischoff, D.A. 1990. Insect resistant cotton. Bio/Technology 8: 939-943

Ryan CA (1973) Proteolytic enzymes and their inhibitors in plants. Ann Rev Plant Physiol 24: 173-196

Ryan CA (1990) Protease inhibitors in plants: genes for improving defenses against insects and pathogens. Annu Rev Phytopath 28: $425-449$

Schaffer HJ, Cushman JC (1994) Characterization of promoter elements required for the salt inducible expression of phosphoenolpyruvate carboxylase in Mesembryanthemum crystallinum. Plant Physiol 105: 128

Schwartz RH (1983) Cotton insect management with special reference to boll weevil. In: Agric Handbook 589 USDA Ridgway RL, Lloyd FP, Cross WH (eds)

Thomas JC, Wasmann CC, Echt C, Robert L, Dunn RL, Bohnert HJ, McCoy TJ (1995) Introduction and expression of an insect proteinase inhibitor in alfalfa (Medicago sativa L.). Plant Cell Reports (in press)

Umbeck P, Johnson G, Barton K, Swain W (1987) Genetically transformed cotton (Gossypium hirsutum L.) plants. Bio/Technology 5: 263-266

Williamson, J.D., Hirsch-Wyncott, M.E., Larkins, B.A. and Gelvin, S.B. 1989. Differential accumulation of a transcript driven by the CaMV 35S promoter in transgenic plants. Plant Physiol, 90: 1570-1576. 